九州大学学術情報リポジトリ

Kyushu University Institutional Repository

\title{
A Computerized Arrangement of Forest Road Using a Digital Terrain Model
}

Cha, Du Song

Department of Forest Management, College of Forestry, Kangweon National University

Nakao, Hiromi

Laboratory of Erosion Control, Faculty of Agriculture, Kyushu University

Watahiki, Kiyoshi

Land-Water Resources and Environment Conservation Section, Institute of Tropical Agriculture, Kyushu University

https://doi.org/10.5109/23978

出版情報：九州大学大学院農学研究院紀要. 36 (1/2)，pp.131-142，1991-10. Kyushu University バージョン：

権利関係 : 


\title{
A Computerized Arrangement of Forest Road Using a Digital Terrain Model
}

\author{
Du Song Cha* Hiromi Nakao** Kiyoshi Watahiki*** \\ * Department of Forest Management, College of Forestry, Kangweon National University, \\ Chuncheon 200-701, Republic of Korea \\ ** Laboratory of Erosion Control, Faculty of Agriculture, Kyushu University, \\ Fukuoka 812, Japan \\ *** Land-Water Resources and Environment Conservation Section, \\ Institute of Tropical Agriculture, Kyushu University, Fukuoka 812, Japan
}

(Received July 30, 1991)

\begin{abstract}
A new method to arrange a forest road with optimum efficiency is proposed by using a digital terrain model under evaluation criteria. The evaluation criteria are based on a harmonious balance between timber production and forest conservation, and consist of design conditions and restriction conditions. Design conditions are the allowable gradient and the density of the forest road.

Restriction conditions are the average skidding distance, ratio of inaccessible points to total points, the maximum skidding distance, standard deviation of skidding distance, development index and weighted average skidding distance. Other conditions can be added or deleted according to the aim of local forest management.

Under these conditions, the optimum forest road can be derived automatically by calculations using a trial and error method.
\end{abstract}

\section{INTRODUCTION}

The purpose of the study

Forest road networks are utilized not only for logging but also for forest production, including reforestation and forest management.

The networks, having multiple functions, however, have never been optimized completely, but are only fully optimum under certain specific management methods and operating systems. In other words, the optimum forest road network should be a combination of the skidding method and the forest road network (Lünzmann 1970).

The method of establishing the evaluation criteria in reference to management methods and of arranging forest roads effectively in target areas are the key factors in forest road arrangement.

In this paper, a computerized arrangement of forest road using a digital terrain model is examined. This method makes the establishment of evaluation criteria possible according to the particular aims of forest management. Under this method, all the routes which connect a starting point to an end point are studied using a trial and error method. Then, an optimum road satisfying all the evaluation criteria can be selected. 


\section{Recent research into forest road arrangement \\ Forest road density}

Peters (1978) described a method to determine both the optimum forest road density and the landing interval in order to minimize the total cost of construction and skidding.

Minamikata (1977) described average forest road density using labor investment costs and cost of transporting workers to the skidding points.

Minamikata et al. (1985) proposed the idea of a synthetic network of forest roads of low and high quality in which different skidding systems were used respectively in two topographically different forests.

\section{Evaluation criteria}

Kitagawa \& Morioka (1983) and Kitagawa (1984) showed that forest road network was a way of facilitating forest management and proposed the following evaluation criteria based on the function of the individual forest road network :

1) Ratio of standard operation area to total area ;

2) Degree demand for arrangement ;

3) Index of investment viability.

Sakai $(1982,1983)$ proposed evaluation criteria relating to the construction cost of forest roads, skidding cost, skidding area, total length of the forest road and average skidding distance.

Kobayashi $(1980,1983,1984)$ proposed the following evaluation criteria :

1) Economic aspects such as the cost of construction and maintenance ;

2) Utility and safety ;

3) Environmental and social effects.

Until now, criteria such as the rate of usable area, average skidding cost relative to average skidding distance, construction cost, maintenance cost and the cost of transporting workers to skidding points have been used (Arimizu, 1965, 1966 ; Hori et al., 1971 ; Hiraga, 1972 ; Fujiwara \& Kamiiizaka, 1980).

Recently, however, the social demand for forests has been increasing, and the criteria, not only for timber product efficiency, but also for the public benefit, have become necessary considerations. For example, the latter criteria are 1) the amount of unstable earth or the area of the denuded surface of a slope 2) the size of the cutting slope (Kitagawa \& Morioka, 1983 ; Kanzaki 1987).

For desirable forest management, the destruction of nature should be minimized by means of selective cutting or clear cutting of small dispersed areas. These operations, however, are very expensive and at the moment no forest road system implements them adequately.

Therefore, high density forest road networks have been proposed. These networks are expected to maximize the public use and benefit of forest land and to realize reasonable timber production at the same time.

\section{Forest road network system}

Lünzmann (1970) showed that a fork type arrangement of forest roads was advantageous, using model analysis comprising a development index. This method focused on the average skidding distance in relatively level areas. 
Kanzaki (1965, 1966, 1974) proposed an arrangement method based on graph theory. That is, the landing points are carefully selected and all the selected points are connected over the shortest distance possible.

Hiraga $(1970,1971,1972)$ proposed the optimum arrangement method of a skidding road on a cut area. This method allows the reduction of the total cost of forest road construction and skidding operations.

Sakai $(1981,1982,1983,1984)$ attempted to establish the optimum arrangement of forest roads using a dynamic programming method. Evaluation criteria were the skidding distance and the total length of the forest road.

Kobayashi $(1980,1983,1984)$ proposed a method to maximize the efficiency of investment in forest road networks using topographical restrictions and forest management conditions.

\section{Characteristics of the method of arrangement}

The outline of the proposed method is as follows :

1) All the potential routes which connect the starting point to the end point by a line are selected using a trial and error method under evaluation criteria (design conditions and restriction conditions).

2) These evaluation criteria can be selected according to the aims of local forest management.

3) Evaluation criteria are examined for all the potential routes and then the optimum route is selected.

It is important to adopt the evaluation criteria according to local demands and requirements, since many criteria relating to forest management have been proposed, as indicated above. Points 1) and 2) make it possible to arrange the forest road automatically taking the criteria into consideration. These points characterize the arrangement method.

\section{METHODOLOGY}

\section{The evaluation criteria used in arrangement}

Evaluation criteria consist of the design conditions and restriction conditions. Here, criteria, significant and widely used, are adopted. Design conditions are the allowable gradient and the density of forest roads which are usually used in the arrangement.

Restriction conditions are listed below. They all relate to skidding operations or forest structure and composition.

(1) The average skidding distance

This criterion is given by

$$
L=\Sigma D / n
$$

where, $L$ : average skidding distance $(\mathrm{m}), D$ : distance from a skidding point to the nearest point on a forest road $(\mathrm{m}), n$ : total number of skidding points in a target area.

(2) ratio of inaccessible points to total points

An inaccessible point is defined as a point where the distance from that point to the nearest point on a forest road is greater than the maximum skidding distance. 
This criterion is given by

$$
\mathbf{R}=(\Sigma m / n) \cdot \mathbf{1 0 0}
$$

where, $R$ : ratio of inaccessible points to total points (\%), $\mathrm{m}:$ the number of inaccessible points, $\mathrm{n}$ : the total number of the points in the target area.

(3) Standard deviation of skidding distance.

This criterion is given by

$$
S_{\mathrm{d}}=\sqrt{\Sigma(D-L)^{2} /(n-1)}
$$

where, $S_{\mathrm{d}}$ : standard deviation of skidding distance $(\mathrm{m})$,

(4) Development index

This criterion (Lünzmann, 1970) indicates the effectiveness of a forest road arrangement. When the arrangement is ideal, the value becomes equal to 1 .

This criterion is given by

$I=\mathrm{d} \cdot \mathrm{L} / 2500$

where, $I$ : development index $\left(\mathrm{m}^{2} / \mathrm{ha}\right), d$ : forest road density $(\mathrm{m} / \mathrm{ha})$.

(5) Weighted average skidding distance

Skidding distances are essentially related to the distribution of skidding volume in the target area. Therefore, the average skidding distance weighted by skidding volume is important.

This criterion is given by

$D_{\mathrm{w}}=\Sigma(D \cdot v) / \Sigma v$

where, $D_{\mathrm{w}}$ : weighted average skidding distance $(\mathrm{m}) . v$ : skidding volume in a point $\left(\mathrm{m}^{3}\right)$.

Any criterion can be added or deleted when necessary.

\section{Procedure for arrangement}

The calculation procedure for forest road arrangement in a target area is as follows.

(1) To establish lattices with each side $1 \mathrm{~cm}$ length on a topographical map, scale $1: 5000$. The length of one side is equivalent to $50 \mathrm{~m}$ in reality. And to make a digital terrain model describing the plain positions and elevations of all the intersecting points of the lattices.

(2) To find the starting point and the end point of forest roads and the impassable points in a target area. In order to make point selection as simply and directly as possible, these impassable points are identified in places such as valleys, ridges, outside the cut area and areas where road construction work is impossible (rock covered areas, collapsed areas and protected forests, etc.)

(3) To set the values of the design conditions and the restriction conditions.

(4) To start point selection from the starting point.

(5) To search all of the neighboring points which have not been considered before.

(6) To extend forest roads to one of those selected points existing within the allowable gradient. If the selected point is the end point, point selection is finished and 


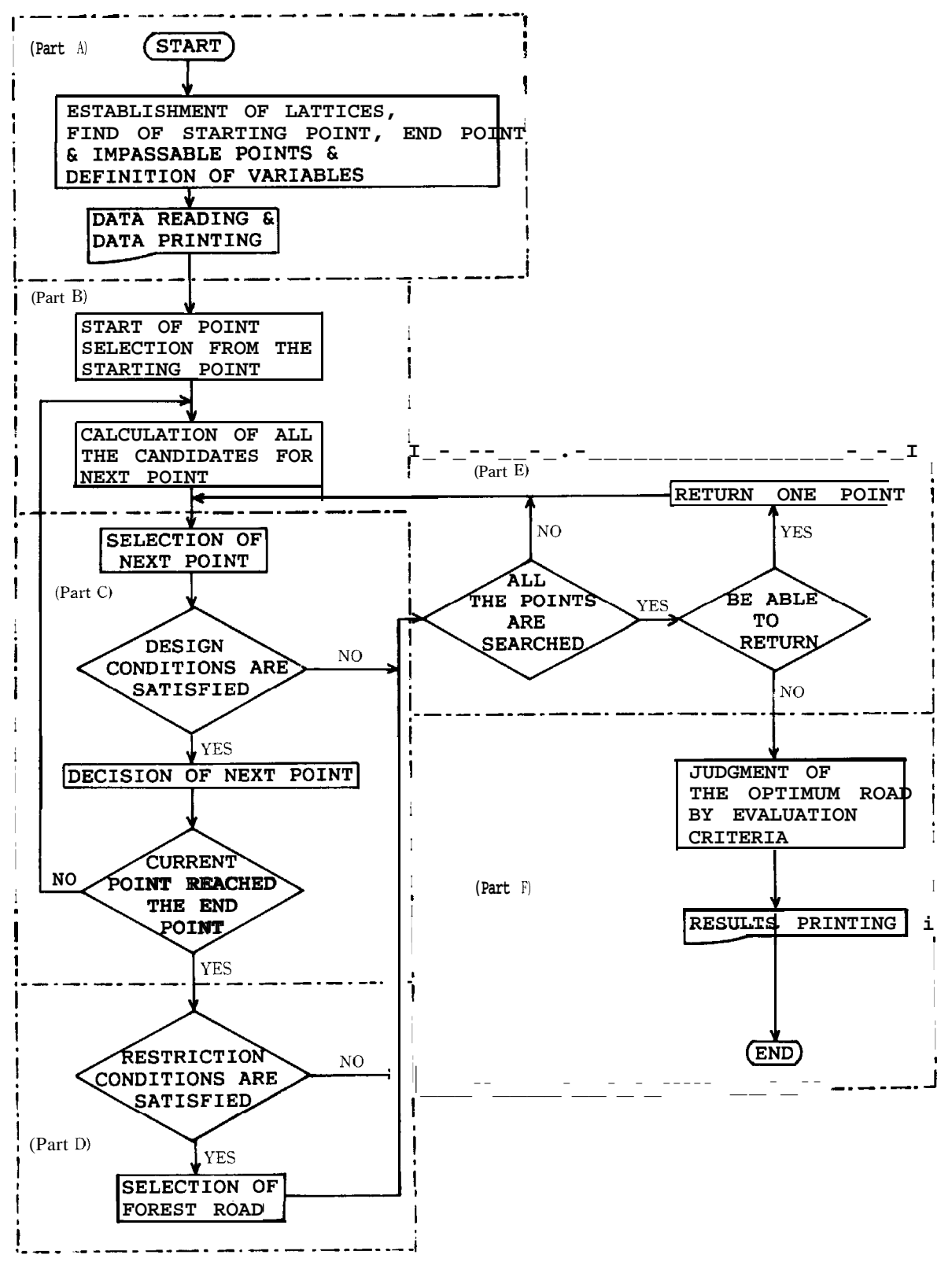

Fig. 1. Flow chart of the calculation procedure for the forest road arrangement 
the process continues on to (7). If the point is not the end point, the process reverts to (5). If there is no neighboring point, the current point is a dead end, and the process advances to (9). Extension to the next (neighboring) point is made in a lengthwise or lateral direction only (i. e. along the sides of the lattice only). The gradient is expressed as the difference in elevation between two points neighboring the current point.

(7) All the skidding points are equivalent to the preyarding points, and the skidding distance is defined as the shortest distance from each skidding point to any point on the determined forest road. Based on the values of skidding distance, average skidding distance, standard deviation of skidding distance, ratio of inaccessible points to total points, the development index and weighted average skidding distance are calculated.

(8) If each $v$ al ue obtained in (7) satisfies each restriction conditions, the road is determined to be a possible candidate for a forest road.

(9) After returning to the previous point from the current point in order to search for another point to pass next, if such a point exists, the next step is (5). If not, (i. e. the route cannot return to the previous point) the current point is the starting point and this situation means that all the possible candidates for the forest road have been selected.

(10) The selected routes having the best value of evaluation among all the possible candidates are judged to be the best suited for forest roads.

The procedures mentioned above are shown in Fig. 1 as a flow chart. In Fig. 1, Part A consists of (1), (2) and (3), Part B of (4) and (5), Part C of (6), Part D of (7) and (8), Part E of (9) and Part F of (10), respectively.

\section{MATERIAL}

Target areas for the arrangement are the unit blocks No. 12 and No. 33, which were established by Cha et al. (1987), in the Hokkaido Forest of Kyushu University. The size of area and topographical characteristics of the blocks are shown in Table 1. In Table 1, terrain index is given by the following expression.

$$
T=1 / 4\left(2\left(n_{1}+n_{2}\right)+R(0.1+0.01 V)\right)
$$

where, $T$ terrain index, $n_{1}$ indicates the number of points of intersection between contours and a circle having a radius of $500 \mathrm{~m}, n_{2}$ indicates the number of intersecting points between contours and a circle having a radius of $250 \mathrm{~m} . R$ indicates the relief energy (the difference between the highest and the lowest points in a circle $500 \mathrm{~m}$ in radius $(m)$ ).

The shapes of both blocks are nearly rectangular. The slope of No. 12 is steep and

Table 1. Area and topographical characteristics of the blocks in the target areas.

\begin{tabular}{lcc}
\hline Block & No. 12 & No. 33 \\
Area (ha) & 29.3 & 25.3 \\
Average slope (\%) & 55.3 & 31.0 \\
Terrain index (\%) & 45.7 & 25.0
\end{tabular}




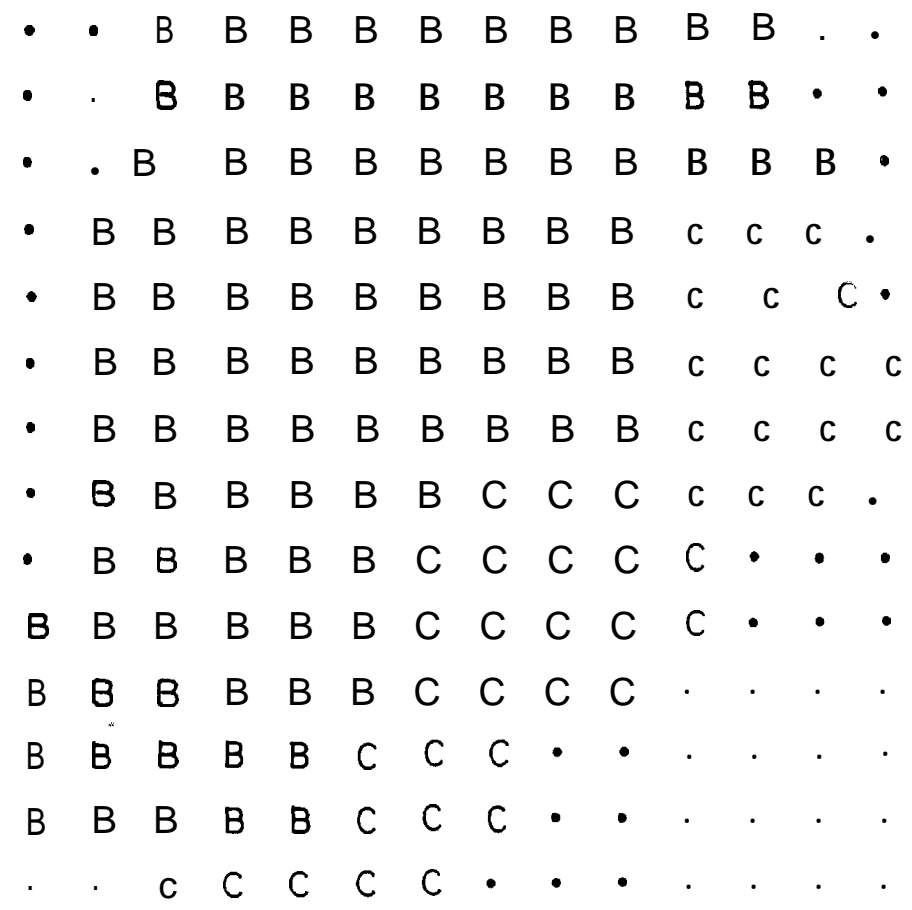

(a) Block No. 12

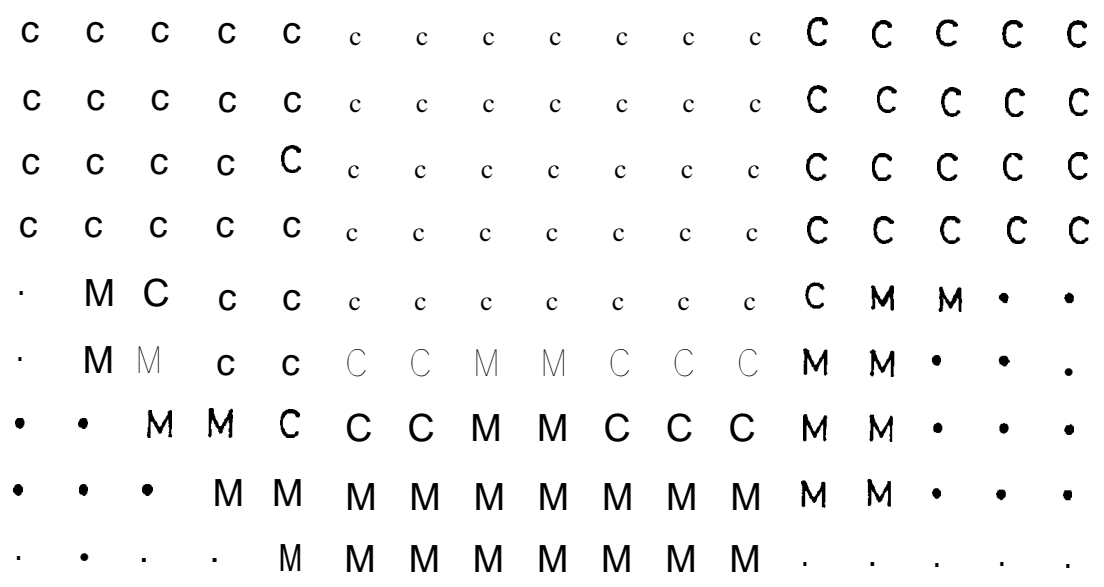

(b) Block No. 33

Fig. 2. Distribution of forest type in the unit blocks

B : Broad-leaved stands (Natural)

c : Coniferous stands (Artificial)

M: Mixed stands 


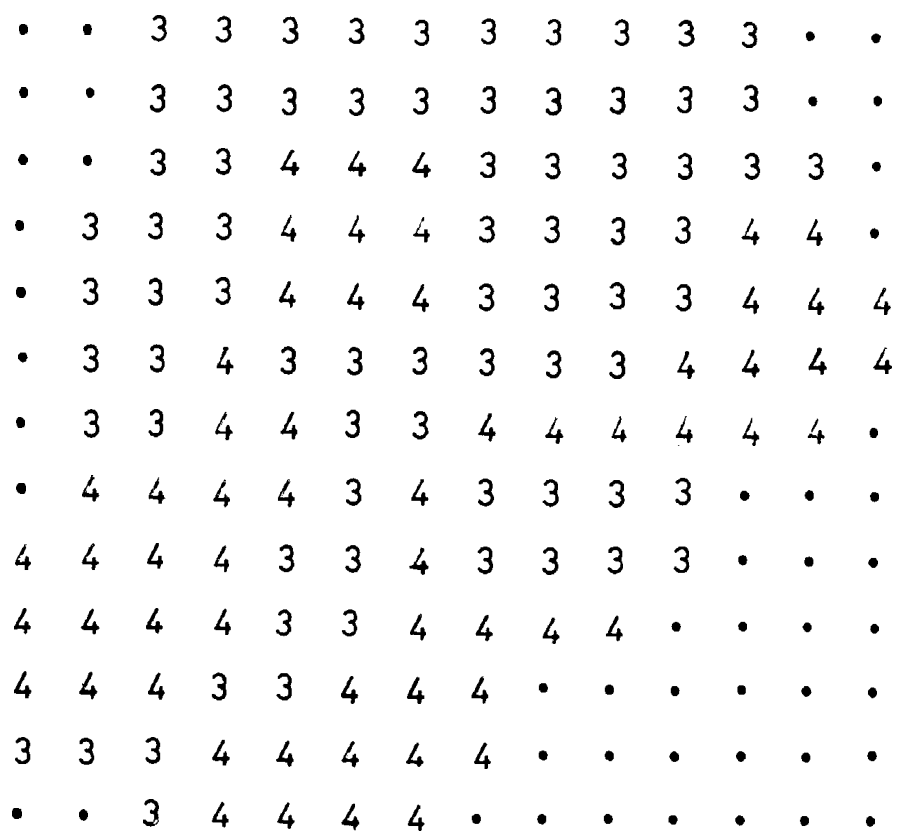

(a) Block No. 12

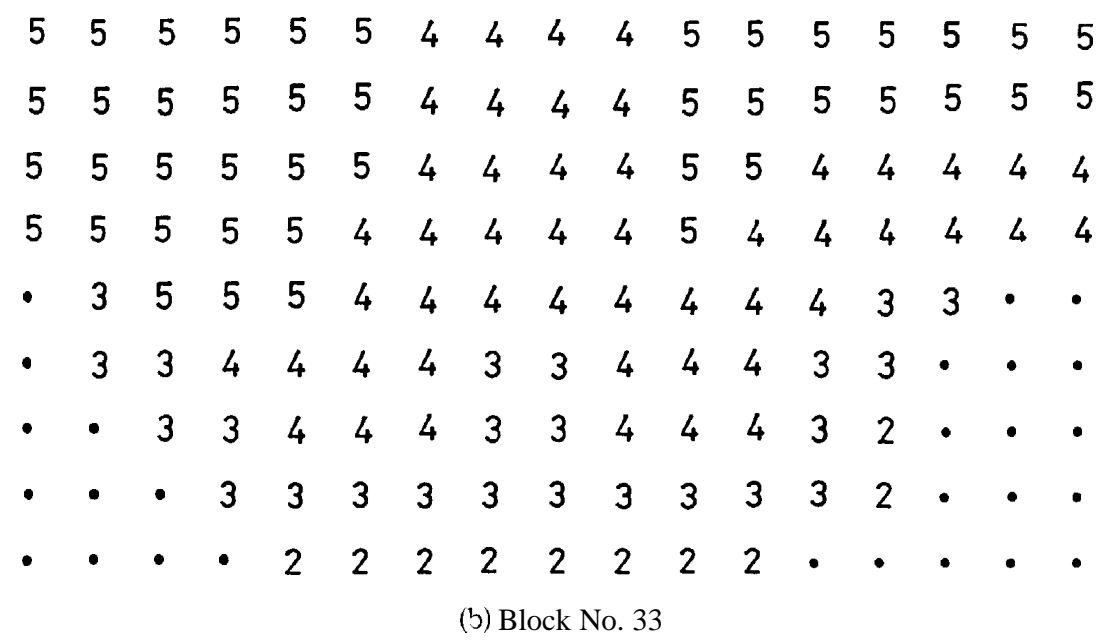

Fig. 3. Distribution of stand volume in the unit blocks

$$
\begin{array}{lrlll}
\text { 1: } & 0-50 & \mathrm{~m}^{3} / \mathrm{ha} & 4: 151-200 & \mathrm{~m}^{3} / \mathrm{ha} \\
\text { 2: } & 51-100 & n & \text { 5: } 201- & 1 . \\
\text { 3: } & 101-150 & n & &
\end{array}
$$


Table 2. Design conditions and restriction conditions.

\begin{tabular}{|c|c|c|c|}
\hline Block & & No. 12 & No. 33 \\
\hline $\begin{array}{l}\text { Design } \\
\text { conditions }\end{array}$ & $\begin{array}{l}\text { Allowable gradient } \\
\text { Forest road density }\end{array}$ & $\begin{array}{r}-22-22 \\
36-43\end{array}$ & $\begin{array}{r}-23-23 \\
50-70\end{array}$ \\
\hline $\begin{array}{l}\text { Restriction } \\
\text { conditions }\end{array}$ & $\begin{array}{l}\text { Average skidding distance } \\
\text { Ratio of inaccessible points to total } \\
\text { points } \\
\text { The maximum skidding distance (m) } \\
\begin{array}{l}\text { Standard deviation of skidding distance } \\
\text { (m) }\end{array} \\
\begin{array}{l}\text { Development index } \\
\text { Weighted average skidding distance (m) }\end{array}\end{array}$ & $\begin{array}{c}70-100 \\
40-50 \\
100 \\
70-80 \\
0.8-1.6 \\
70-100\end{array}$ & $\begin{array}{c}50 \quad 100 \\
O-25 \\
100 \\
30-80 \\
0.8-1.7 \\
50-100\end{array}$ \\
\hline
\end{tabular}

Table 3. Results of the values of evaluation criteria.

\begin{tabular}{|c|c|c|c|}
\hline Block & & No. 12 & No. 33 \\
\hline & Forest road density & 43.0 & 69.3 \\
\hline \multirow{5}{*}{$\begin{array}{l}\text { Evaluation } \\
\text { values }\end{array}$} & Average skidding distance & 98.0 & 53.5 \\
\hline & $\begin{array}{l}\text { Ratio of inaccessible points to total } \\
\text { points }\end{array}$ & 44.1 & 6.4 \\
\hline & Standard deviation of skidding distance & 71.6 & 43.4 \\
\hline & Development index & 1.46 & 1.5 \\
\hline & Weighted average skidding distance $(\mathrm{m})$ & 96.0 & 52.6 \\
\hline
\end{tabular}

that of No. 33 is relatively gentle. Distributions of stand type and standing tree volume in each block are shown in Fig. 2 and Fig. 3, respectively. The design conditions and the restriction conditions are shown in Table 2.

\section{RESULTS AND DISCUSSION}

Based on the method of calculation above, forest road arrangements are carried out. Design conditions and restriction conditions are shown in Table 3. Results of the forest road arrangement are shown in Fig. 4 and the values of evaluation criteria are shown in Table 3.

Here, the route having the minimum development index value is selected as the optimum road from amongst several candidates. In cases where there are numerous candidates, the kind of value that should be emphasized in the selection and how to select the optimum road considering all the values synthetically, arise as new questions.

The candidates have a tendency to appear near the optimum route. A route being different in only one adjacent point from one route is recognized as a new route. Since the route shape will be modified in subsequent road alignment (right-angled corners on 


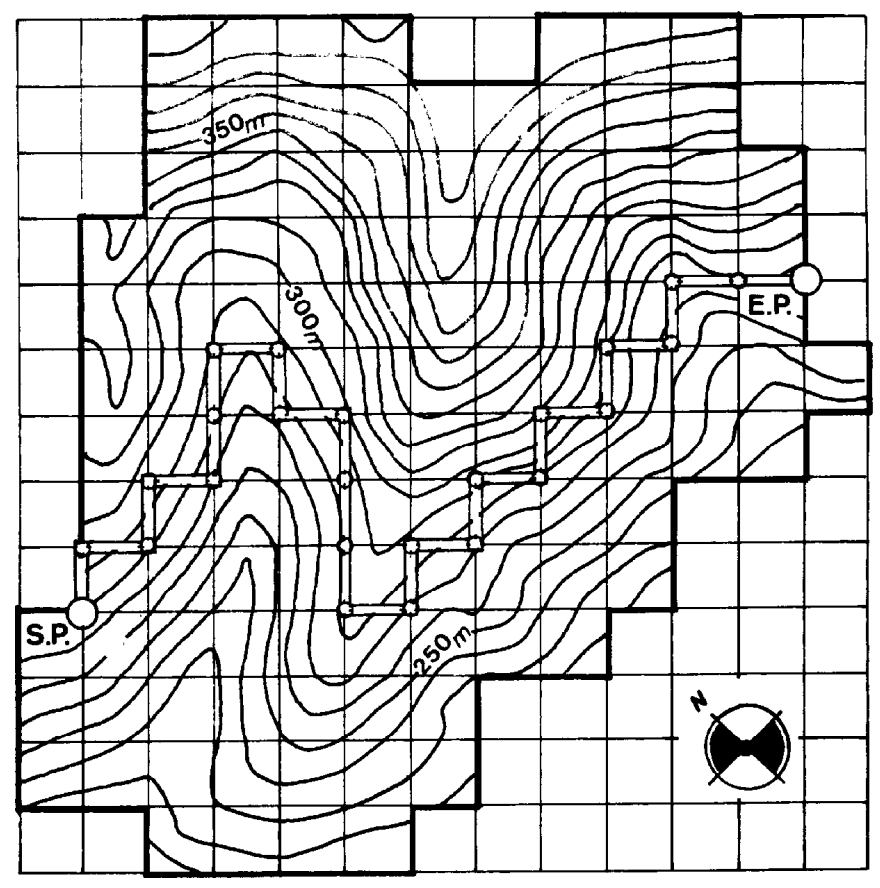

Fig. 4-1. Example of forest road arrangement (Block No. 12)

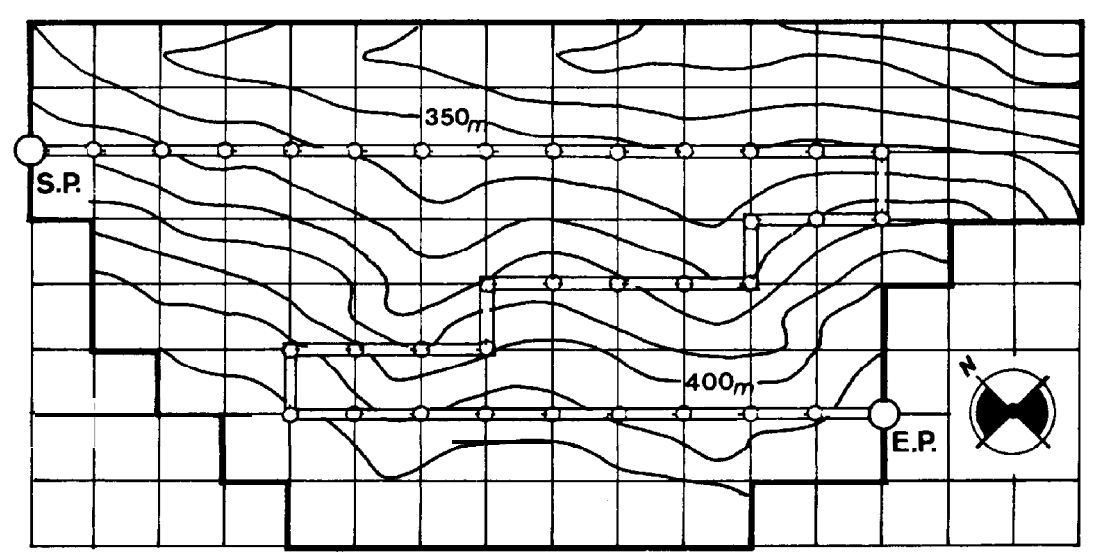

Fig. 4-2. Example of forest road arrangement (Block No. 33) 
the chosen road will be replaced by circular edges) in actual practice, slight differences between the routes are not very significant. To recognize the routes as one route, some mechanical device would be needed. That would make the calculation more efficient.

Actually with subsequent road alignment, the steepest slope in a route will become gentler. It is important on steep slopes to find the allowable slope based on statistical or other analyses of the relationship between the calculated and actual slope.

\section{CONCLUSIONS}

In this method, a next point is not allowed to be in an oblique direction in order to make the process of calculation simple. In cases where numerous meshes are established in an area, the impact of this directional limitation is not so pronounced, because the route closely resembles steps. However, the larger the number of meshes in an area, the greater the number of candidates becomes and calculation time becomes greater. To solve this problem, various mechanical devices are needed for further study.

An arranged road is quite simple, since it has only one route with no diverging routes. However, that road might not be very functional under real conditions. But, certain mechanical devices, such as the following, can make the route closer to an actual one :

1) To divide an observed area into small areas.

2) To lengthen a route to make it the same quality as a route with diverging routes.

The calculations were done by a FACOM computer at Kyushu University.

\section{REFERENCES}

Arimizu, T. 1965 Density of Rorest Foad (1) -Introduction. Bull. Gov. For. Exp. Sta., 173: 81-91

Arimizu, T. 1966 Density of Forest Road (2) Capacity cost. Bull. Gov. For. Exp. Sta., 191: 137-156

Cha, Du Song, et al. 1987 Planning of Forest Road Network in Palm Form Working System (1) Establishment of Unit Block-. J.Fac.Agr., Kyushu Univ., 32 (1, 2) :129-139

Fujiwara, N. \& Kamiiizaka, M. 1980 Transition of Forest Road Density in Timber Production Areas -An Investigation in the Imaichi District-. J. Jpn. For. Soc., 62(2) : 39-45

Hiraga, M. 1970 Densanshuhou niyoru Sagyoudoumou Keikakuhou. (in Japanese) Trans. 81 th $\mathrm{mtg}$. Jpn. For. Soc., 360-361

Hiraga, M. 1971 Studies on the Forest Road Network with the Use of Electronic Computer (1) A method of determining the optimum passing points and the density on the logging road. Bull. Gov. For. Exp. Sta., 238: 1-30

Hiraga, M 1972 Studies on the Forest Road Network with the Use of Electronic Computer (2) A method of determining the logging road network adapting the simple form patterns. Bull. Gov. For. Exp. Sta., $245: 99-158$

Hiraga, M. 1972 J. B. Hou niyoru Rindou Tuukaten Ketteisyuhou nituite. (in Japanese) Trans. 83 th mtg. Jpn. For. Soc., 423-424

Hori, T. et al. 1971 Study on the Area Distribution of the Terrain Distances in a Forest. J. Jpn. For. Soc., 53 (11): $355-358$

Kanzaki, K. 1965 Outline on the Theory of Graphs Usable for Planning the Forest Road Network. J. Jpn. For. Soc., 47 (2) : 84-87 
Kanzaki, K. 1966 A Planning of the Forest Road Network by the Theory of Graphs. J. Jpn. For. Soc., 48 (10): 365-371

Kanzaki, K. 1974 On a Mathematical Method of Determining Forest Road Line. J. Jpn. For. Soc., 56 (12) : 415-424

Kanzaki, K 1987 Bassyutu Sagyou womeguru Shomondai. (in Japanese) Ringyo Gijutsu, 549 :16-19

Kitagawa, K \& Morioka, N. 1983 Estimate of Requirements for Forest Road Construction in Relation to Forest Operation. (in Japanese) Trans. 94th mtg. Jpn. For. Soc., 699-702

Kitagawa, K. 1984 A New Logical System for Forest Road Network Planning, IUFRO Proceedings Kyoto, 353-362

Kobayashi, H. 1980 Studies on Planning Methods of Forest Road Network, Forest Road Planning Methods for Maximum Economic Effect. Trans. 91 th mtg. Jpn. For. Soc., 459-460

Kobayashi, H. 1983 Studies on the Forest-Road Network Planning System in Mountain Forests. Special Bull. College Agr.Utsunomiya Univ., 38 :1-101

Kobayashi, H. 1984 Planning of system for Road Route Location in Mountainous Forests. J.Jpn. For. Soc., 66 (8) : 313-319

Lünzmann, K. 1970 Der Erschließungskoeffizient, ein Kenzahl zur Beurteilung von Waldwegenezen und Seine Anwendung bei Neuplanungen. (translated into Japanese) Journal of the forestry Mechanization society, 205 :27-39

Minamikata, Y. 1977 On the Essential Road Network to Forestry and Forest Conservation. J.Jpn. For. Soc., 59 (8) : 298-300

Minamikata, Y. et al. 1985 Planning of Synthetic Forest-Road Networks of High and Low Quality. Bull. Tokyo Univ. For., 74: 81-96

Peters, P. A. 1978 Spacing of Roads and Landing to Minimize Timber Harvest Cost. Forest Sci., 24 : 209-217

Sakai, T. 1981 Studies on Planning Method of a Forest Road in Mountainous Region, Using a Simulation Model. Bull. Kyoto Univ. For., 53: 162-171

Sakai, T. 1982 Studies on Planning Method of Forest Road Network (I) -Elimination of Unavailable End Points. Bull. Kyoto Univ. For., 54: 172-177

Sakai, T. 1983 Studies on Planning Method of Forest Road Network (II) -Evaluation by Skidding Distance and Road Length for Optimum Network. Bull. Kyoto Univ. For., 55 : 222-229

Sakai, T. 1984 Studies on Planning Method of Forest Road Network (III) -Analysis of Spur Road for Reforestation in Private Forest Using a Distance between Road and Working Place-. Bull. Kyoto Univ. For., 56: 166-177 